GRASAS Y ACEITES 70 (3)

July-September 2019, e315

ISSN-L: 0017-3495

https://doi.org/10.3989/gya.0936182

\title{
Effect of pollen sources on yield oil extraction and fatty acid profile of the date seed (Phoenix dactylifera L.) cultivar Medjool from Mexico
}

\author{
C. García-González ${ }^{\mathrm{a}}, \mathrm{R}$. Salomón-Torres ${ }^{\mathrm{b}, 凶}$, G. Montero-Alpírez ${ }^{\mathrm{a}}, \mathrm{D}$. Chávez-Velascoc ${ }^{\mathrm{c}}$, \\ N. Ortiz-Uribe ${ }^{\mathrm{b}}$, N.S. Ruiz-Ortiz ${ }^{\mathrm{b}}$, M.A. Coronado-Ortega ${ }^{\mathrm{a}}$ and M.A. Curiel-Alvarez ${ }^{\mathrm{a}}$ \\ ${ }^{a}$ Universidad Autónoma de Baja California, Instituto de Ingeniería, Mexicali, B.C., México. \\ ${ }^{\mathrm{b}}$ Universidad Estatal de Sonora, Departamento de Posgrado, San Luis Rio Colorado, Sonora, México. \\ ${ }^{c}$ Tecnológico Nacional de México/Instituto Tecnológico de Tijuana. Centro de Graduados e Investigación en Química, \\ Tijuana, B.C., México. \\ ${ }^{\square}$ Corresponding author: ricardo.salomon@ues.mx
}

Submitted: 21 September 2018; Accepted: 04 December 2018. Published online: 26 April 2019

\begin{abstract}
SUMMARY: The present investigation aimed to assess the effect of pollen sources on the mass, dimension, oil content and fatty acid profile of the seeds from female palms of the Medjool date cultivar. The palms were pollinated with Deglet Noor, Khadrawy, Medjool and Zahidi cultivars. In addition, three palms were pollinated as the treatment control. The fatty acids were evaluated by gas chromatography-mass spectrometry. The surface morphology of date seed powder was examined using SEM, before and after n-hexane interaction. The seeds of the Medjool treatment had the greatest mass $(1.42 \mathrm{~g})$, but the lowest oil content $(5.37 \% \mathrm{w} / \mathrm{w})$; the control seeds showed smaller mass $(1.21 \mathrm{~g})$, but higher oil content $(13.57 \% \mathrm{w} / \mathrm{w})$. The proportion of fatty acids varied significantly among the treatments with respect to the control. The most abundant fatty acids were oleic (C18:1), lauric (C12:0), myristic (C14:0), palmitic (C16:0), linoleic (C18:2), and stearic (C18:0). Together these fatty acids presented a composition between 98.3 and $98.67 \%$ for treatments, and $99.0 \%$ for the control. The results indicate that the pollen sources from Deglet Noor, Khadrawy, Medjool and Zahidi cultivars had a significant effect on mass, dimension, oil content and fatty acid profile of the seeds of the date cultivar Medjool. The date seed oil could be used as edible oil, in food products, and in pharmaceutical and cosmetic applications.
\end{abstract}

KEYWORDS: Date seed; Fatty acid profile; Medjool; Oil; Pollination

RESUMEN: Efecto de las fuentes de polen sobre el rendimiento en la extracción de aceite y perfil de ácidos grasos de las semillas de dátil (Phoenix dactylifera L.) cultivar Medjool de México. La presente investigación tuvo como objetivo evaluar el efecto de las fuentes de polen, sobre la masa, dimensión, contenido de aceite y el perfil de ácidos grasos de las semillas de dátil del cultivar Medjool. Las palmas hembras del cultivar Medjool fueron polinizadas con cultivares Deglet Noor, Khadrawy, Medjool y Zahidi. Además, tres palmas fueron polinizadas como tratamiento control. Los ácidos grasos se evaluaron por cromatografía de gases-espectrometría de masas. La morfología de la superficie del polvo de semillas de dátil se examinó utilizando un equipo SEM, antes y después de la interacción n-hexano. Las semillas del tratamiento Medjool resultaron con mayor masa (1,42 g), pero menor contenido de aceite $(5,37 \% \mathrm{p} / \mathrm{p})$; la semilla control, mostró una masa más pequeña $(1,21 \mathrm{~g})$, pero un mayor contenido de aceite $(13,57 \%$ p/p). La composición de ácidos grasos varió significativamente entre los tratamientos con respecto al control. Los ácidos grasos mayoritarios fueron: oleico (C18:1), láurico (C12:0), mirístico (C14:0), palmítico (C16:0), linoleico (C18:2) and esteárico (C18:0). En total, estos ácidos grasos alcanzan una composición entre 98.3 y $98.67 \%$ para los tratamientos, y $99.0 \%$ para el control. Los resultados indican que la fuente de polen de los cultivares Deglet Noor, Khadrawy, Medjool y Zahidi tiene un efecto significativo sobre la masa, dimensión, contenido de aceite y el perfil de ácidos grasos de la semilla del cultivar de dátil Medjool. El aceite de la semilla de dátil, podría usarse como aceite comestible, productos alimenticios, aplicaciones farmacéuticas y cosméticas.

PALABRAS CLAVE: Aceite; Medjool; Perfil de ácidos grasos; Polinización; Semilla de dátil

ORCID ID: García-González C https://orcid.org/0000-0002-9913-2905, Salomón-Torres R https://orcid.org/0000-00026486-2131, Montero-Alpírez G https://orcid.org/0000-0002-4659-0099, Chávez-Velasco D https://orcid.org/0000-00022061-9455, Ortiz-Uribe N https://orcid.org/0000-0003-3425-5143, Ruiz-Ortiz NS https://orcid.org/0000-0001-6391-0966, Coronado-Ortega MA https://orcid.org/0000-0002-4045-4272, Curiel-Álvarez MA https://orcid.org/0000-0002-4141-1020

Citation/Cómo citar este artículo: García-González C, Salomón-Torres R, Montero-Alpírez G, Chávez-Velasco D, Ortiz-Uribe N, Ruiz-Ortiz NS, Coronado-Ortega MA, Curiel-Álvarez MA. 2019. Effect of pollen sources on yield oil extraction and fatty acid profile of the date seed (Phoenix dactylifera L.) cultivar Medjool from México. Grasas Aceites 70 (3), e315. https://doi.org/10.3989/gya.0936182

Copyright: (C2019 CSIC. This is an open-access article distributed under the terms of the Creative Commons Attribution 4.0 International (CC BY 4.0) License. 


\section{INTRODUCTION}

The date palm (Phoenix dactylifera L.) is symbolic of warm climates and is cultivated for its edible delicious sweet fruit. The production in México in 2017 was 8,215 tons, harvested from an area of 1,377 ha (SIAP, 2018). A proportion of $95 \%$ of the production corresponds to the Medjool cultivar; the rest corresponds to other cultivars such as Deglet Noor, Khadrawy, Zahidi, Bahree, Honey, Hallawy and creole dates.

The date palm plant is unisexual, being either male or female. Flowers grow on inflorescences called spathes, which open naturally when ready to start the pollination process (Rahnama and Rahkhodaei, 2014). The pollination of date palm involves the transfer of the pollen produced by the male palms, until it comes into contact with the flowers of the female palm to fertilize the ovules contained in the flower, and to share half the genetic material required for the production of the date fruit (Georgi, 1982).

The natural form of pollination of the date palm is mainly due to the action of the wind and bees. However, for commercial production, it is necessary to carry out artificial pollination in order to increase the percentages of fruit. The pollen obtained from a single male palm can pollinate from 50 to 100 female date palms. Pollen has extensive effects on the chemical, quality and quantity characteristics of date fruit and seeds (Salomon-Torres et al., 2017). Therefore it is important to choose proper pollen for pollination because this specification affects the size of the fruit and seed, development rate and time of fruit ripening (Hussein et al., 1979; Swingle, 1928).

When the date is in its ripeness stage (Tamar), the harvest begins, and usually, the seed is discarded as waste once the flesh is removed, since the last part is the edible part. The industrial exploitation of date seeds in Mexico is null, due to various factors such as lack of knowledge on the part of producers for the valorization of the seed, as well as the lack of infrastructure and specialized supplies.
The date seed, depending on variety and quality grade, contains between $6-12 \%$ of the total fruit weight in its ripe stage (Barreveld, 1993). An alternative use for the date seed is through the exploitation of its oil content (Aljuhaimi et al., 2012), which can be extracted by several physical and chemical techniques, the most common by organic solvents. Some applications of date seed oil can replace portions of other fruit oils such as palm or coconut oil in food and toilet product formulations, among others.

The aim of the present study was to assess the effect of pollen sources, on the mass, dimension, oil content and fatty acid profile of the Medjool date cultivar seed under the conditions of the Northwest of Mexico.

\section{MATERIALS AND METHODS}

\subsection{Pollination}

The studies were carried out in a plantation of female recipients of the Medjool cultivar of 17 years of age and vigor, located in the San Luis Rio Colorado Valley, in Northwest Mexico (Latitude: $32^{\circ} 23^{\prime} 5^{\prime \prime}$, Longitude: $\left.114^{\circ} 53^{\prime} 55^{\prime \prime}\right)$. The pollen was extracted from male creole palms of the most common cultivars of the agricultural area, which are Medjool, Deglet Noor, Khadrawy, and Zahidi cultivars. These were used as the sources of pollen for the pollination of the Medjool cultivar. Male inflorescences were collected once the spathes were naturally broken; they were then transported to a drying area, the inflorescences were hung separately during a 3-day period and the pollen was collected daily on a paper bed (Abdeloauhhab and Arias-Jimenez, 1999). The pollen was stored at $4{ }^{\circ} \mathrm{C}$ until pollination time. The interaction of pollination is exemplified in Figure 1.

Pollen preparation for the four treatments and control consisted of mixing with commercial wheat flour in a 1:1 ratio, according to the traditional method of Mexican farmers to prepare pollination mixtures. The pollen from the control

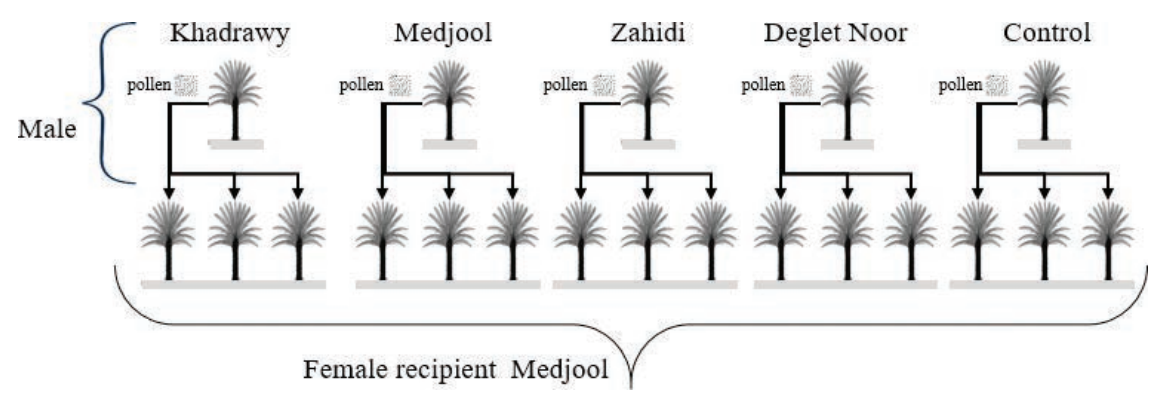

Figure 1. Design of pollination process in female Medjool recipients. 


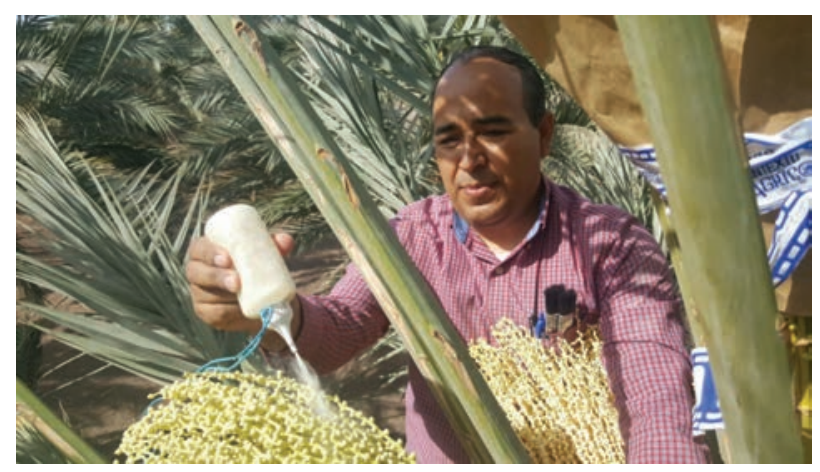

FIGURE 2. Manual pollination using a plastic squeeze bottle as container for the pollination mixture on female Medjool inflorescences.

treatment was composed of a mixture of pollen from different sources in unknown proportions, which is the traditional method for manual pollination (Figure 2).

The pollination process was carried out manually using a plastic squeeze bottle as container for the pollination mixture on female inflorescences, between the third and seventh day after the spathe had broken, according to Salomon-Torres et al., (2017).

\subsection{Sampling and sample preparation}

During the 2017 harvest season 100 dates were collected from each treatment. The seeds were removed from the date flesh and soaked in clean water to free of any adhering date flesh and then were air-dried at $40{ }^{\circ} \mathrm{C}$. Date seeds from each treatment were separately milled in a heavy-duty grinder to pass 1-2 $\mathrm{mm}$ screens and then preserved at $20^{\circ} \mathrm{C}$ for further analyses.

\subsection{Physical properties}

A hundred samples were taken randomly from each treatment to determine date seed weight and dimension (length and diameter). The weight was determined using an analytical balance, and the length and width of the seeds were then measured using a caliper micrometer.

\subsection{Seed oil extraction}

Oil extraction was performed according to the method described by AOAC 963.15 (2005). Briefly, $10 \mathrm{~g}$ of date powder were extracted with $200 \mathrm{~mL}$ of $\mathrm{n}$-hexane in a Soxhlet extractor for $6 \mathrm{~h}$. The n-hexane was removed by evaporation using a rotary evaporator at $80^{\circ} \mathrm{C}$ in a water bath. The extracted oil was kept in glass vials and stored at $-4{ }^{\circ} \mathrm{C}$ until fatty acid methyl ester (FAME) preparation. All extraction processes were performed in triplicate and the yield was expressed as percent of oil (w/w) obtained based on the weight of date seed powder used.

\subsection{Date seed powder surface morphology}

The date seed powder was analyzed using a Scanning Electron Microscope (SEM) JEOL JSM- 6360 to examine the external surface of the date seed powder and to identify the morphology changes occurring on the surfaces due to the effect of contact with n-hexane. The conditions were constant in the two images, such as acceleration voltage of $15 \mathrm{kV}$ and a vacuum of $50 \mathrm{~Pa}$ due to the nonconductive nature of the sample.

\subsection{Fatty acid methyl ester preparation}

The evaluation of fatty acids in date seeds requires conversion into FAME in order to improve volatility and reduce tailing in the chromatogram's peak with good precision and reproducibility (Cert et al., 2000). In this study, the AOCS method Ce 2-66 (1997) was used for FAME preparation, according to the process clearly illustrated by Akbari et al., (2012).

\subsection{GC/MS analysis}

The analyses were performed using an Agilent 7890A GC coupled to 5975C Mass detector Agilent Technologies, equipped with a HP-5MS capillary column $(30 \mathrm{~m} \times 0.25 \mathrm{~mm} \times 0.25$ micron $)$ Agilent Technologies, Inc. An Agilent Technologies 7693 auto sampler was used to inject $1 \mu \mathrm{L}$ of solution sample. The ionization energy was $70 \mathrm{eV}$ with a mass range of 30 to $800 \mathrm{~m} / \mathrm{z}$. The initial temperature of the column at $125^{\circ} \mathrm{C}$, held for $0.5 \mathrm{~min}$, ramped at $25^{\circ} \mathrm{C} / \mathrm{min}$ to $150^{\circ} \mathrm{C}$, held for $2 \mathrm{~min}$, then up to $200{ }^{\circ} \mathrm{C}$ with a $50{ }^{\circ} \mathrm{C} / \mathrm{min}$ rate. The temperature of the injector was set at $255^{\circ} \mathrm{C}$ and the detector to $270{ }^{\circ} \mathrm{C}$. The flow rate of the carrier gas (Helium) was $1.0 \mathrm{~mL} / \mathrm{min}$ injected with a gas dilution of 1:50. Identification of the individual components was based on comparison with the mass spectra library (NIST98). All determinations were carried out in triplicate.

\subsection{Statistical analysis}

The collected data were subjected to the one-way analysis of variance (ANOVA). The means of the results were compared by multiple comparisons of means by the least significant differences (LSD) test, at a significance level of 5\% (Steel and Torrie, 1980). The statistical analysis was calculated using version 3.5.0 of Statistical Software R (Kabacoff, 2011; R Core Team, 2015). Finally, the results of fatty acid profile were expressed as mean values \pm standard deviation of the three separate determinations per sample. 


\section{RESULTS}

\subsection{Date seed physical properties}

The diameter, length and weight of the seeds were measured. Means followed by the same letter(s) in a column do not differ significantly at 0.05 probability level. These parameters are commonly used by farmers to evaluate the quality of date seeds. The results are depicted in Figure 3.

The dimensions of the seeds of the treatments were measured for diameter and length and were on average 0.89 and $2.63 \mathrm{~cm}$, respectively. The seeds with the smallest dimensions were from the treatment with Deglet Noor pollen showing values of 0.88 and $2.55 \mathrm{~cm}$ for diameter and length, respectively. The seeds with the greatest dimensions were from the treatment Medjool with $0.91 \mathrm{~cm}$ in diameter and Khadrawy with $2.71 \mathrm{~cm}$ in length. While the dimensions for the control seeds were 0.84 and $2.47 \mathrm{~cm}$.

The weight of the seeds obtained from the treatments showed an average of $11 \%$ more mass than the control; whereas the lowest values corresponded to the Deglet Noor treatment, which was $9 \%$ heavier than the control. The largest seed mass was induced by the Medjool pollen, and was $17 \%$ higher than the control treatment, which averaged $1.21 \mathrm{~g}$.

\subsection{Oil yield}

The oil contents in the date seeds, expressed as percentages, are shown in Figure 4. The oil contents in date seed treatments were the highest for Zahidi (11.09\%) and lowest for Medjool (5.37\%). The control treatment showed the highest content $(13.5 \%)$.

The results of oil content vary considerably according to the source of the pollen on the female recipient Medjool cultivar. The treatments 6.22 and $8.56 \%$ for Khadrawy and Deglet Noor, respectively, showed higher oil contents than the Medjool treatment, but lower oil extraction yields than the control $(13.57 \%)$.

\subsection{Date seed powder surface morphology}

Representative micrographs of powdered date seed surface before and after interaction with n-hexane were obtained through SEM and are presented in Figure 5. The images are representative of all treatments and control, and were taken at a magnification of $200 \mathrm{X}$.

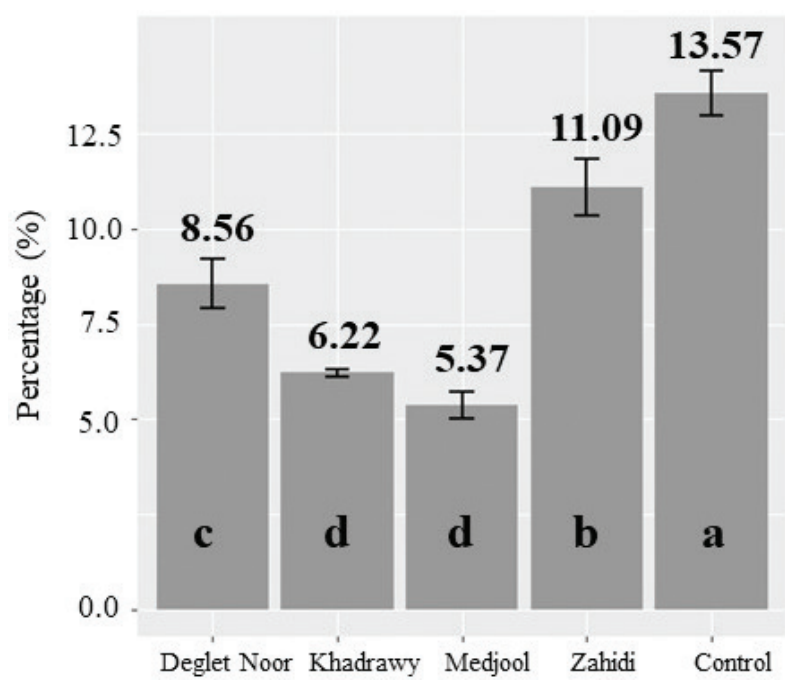

Figure 4. Date seed treatment oil content. Values are mean $\pm \mathrm{SD}$ of three independent determinations. The collected data were submitted to analysis of variance (ANOVA), and were compared by a multiple comparison of means according to the least significant differences (LSD) test at a significance level of 5\%. Means followed by same letter(s) in a column do not differ significantly.
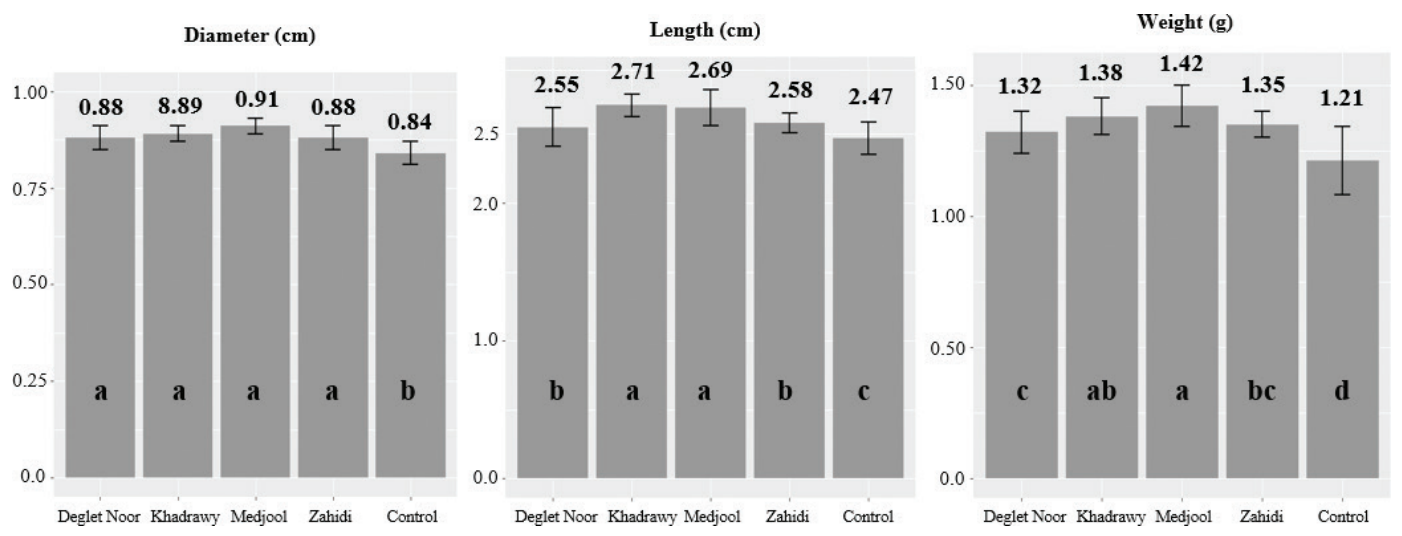

FIGURE 3. Date seed treatment physical characterization (diameter, length and weight). Values are mean \pm SD of 100 samples. The collected data were submitted to analysis of variance (ANOVA), and were compared by a multiple comparison of means according to the least significant differences (LSD) test at a significance level of $5 \%$. Means followed by the same letter(s) in a column do not differ significantly. 
In Figure 5a, a pattern of irregularly shaped and randomly distributed cells was identified to have a width between $30-50 \mu \mathrm{m}$, and length between 30 and $60 \mu \mathrm{m}$. In Fig. 5b, no pattern of cells was identified, only a solid mixture of different sizes in disorder was observed, caused by the interaction of the organic solvent used to remove the oil contained in the date seed powder. The aggressive effect of the organic solvent on the surface of the date seed powder can be observed clearly.

\subsection{Date seed powder surface morphology}

The oil composition of the date seed was identified and quantified as FAME. The chromatogram is shown in Figure 6, and is presented as general for all treatments and the control, since the retention times of the FAME's were the same. Thirteen peaks were identified for Deglet Noor, Medjool and Zahidi; while for the Khadrawy and the control only twelve peaks were detected.
The relative concentrations of the fatty acids of date seed oil in the treatments and control were as follows: oleic (C18:1), > lauric (C12:0), $>$ myristic $(\mathrm{C} 14: 0),>$ palmitic $(\mathrm{C} 16: 0),>$ linoleic (C18:2), > stearic (C18:0). Taken together these fatty acids composed of around $98.3-98.67 \%$ for the treatments, and $99.0 \%$ for the control. The following compounds were found in amounts less than $0.5 \%$ for all treatments and control: caprylic (C8:0), capric (C10:0), palmitoleic (C16:1), margaric $(\mathrm{C} 17: 0)$, arachidic $(\mathrm{C} 20: 0)$, gondoic $(\mathrm{C} 20: 1)$, trans-gondoic (C20:1). The complete fatty acid compositions of the date seed oil for treatments and control, detected throughout the study are listed in Table 1.

Lauric acid $(\mathrm{C} 12: 0)$ was found to be the predominant SFA in the date seed oil treatments studied $(17.06-17.6 \%)$ and the control date seed oil (17.24\%). Palmitic (C16:0) and myristic acids (C14:0) followed with very close values for the treatments $(10.36-10.86 \%)$, while for the control
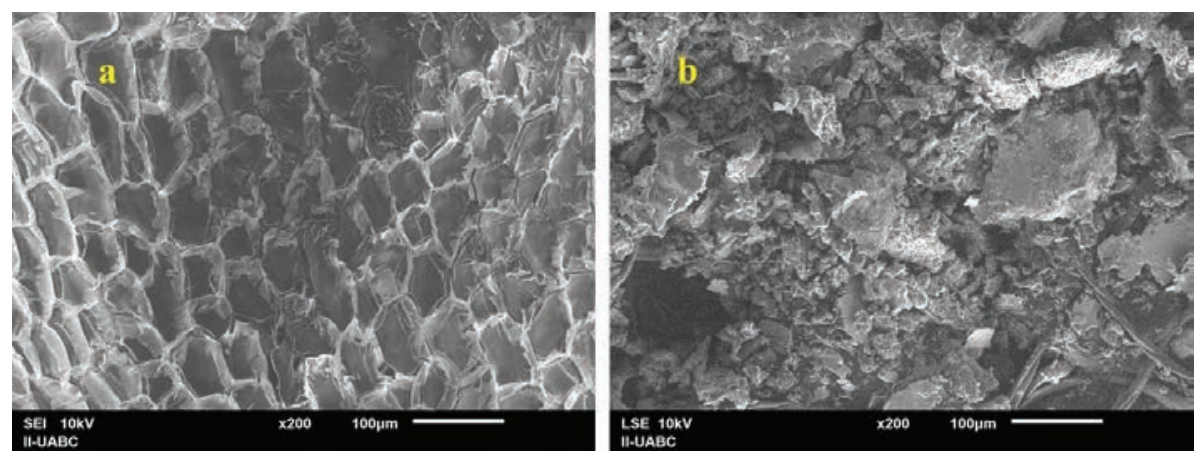

Figure 5. Scanning electron microscope micrograph of date seed powder at 200x before (a) and after $n$-hexane interaction by Soxhlet (b).

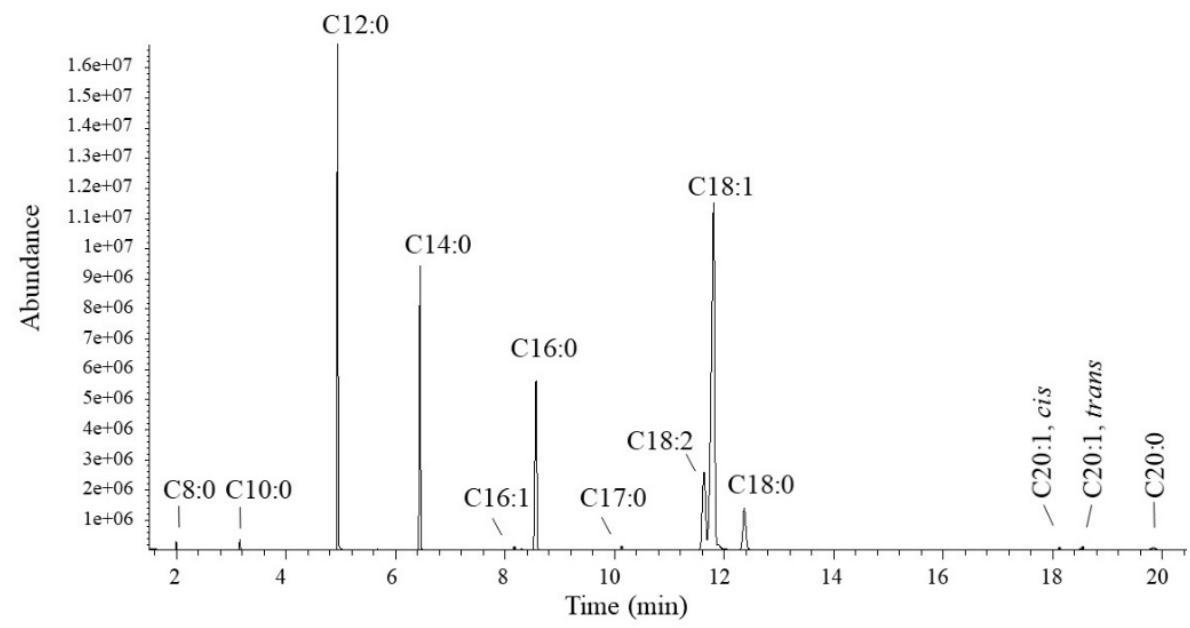

FIGURE 6. GC-MS general for fatty acid methyl esters from date seed oil for all treatments and control; (C8:0) Caprylic acid, (C10:0) Capric acid, (C12:0) Lauric acid, (C14:0) Myristic acid, (C16:0) Palmitic acid, (C16:1) Palmitoleic acid, (C17:0) Margaric acid, (C18:0) Stearic acid, (C18:1) Oleic acid, (C18:2) Linoleic acid, (C20:1) Gondoic acid, (C20:1) trans-gondoic acid, (C20:0) Arachidic acid 
TABLE 1. Fatty acid profiles of date seed oil, expressed in percent of the total fatty acids.

\begin{tabular}{|c|c|c|c|c|c|}
\hline Fatty acid & Deglet Noor & Khadrawy & Medjool & Zahidi & Control \\
\hline (C8:0) Caprylic & $0.28 \pm 0.00^{\mathrm{a}}$ & $0.27 \pm 0.00^{\mathrm{a}}$ & $0.27 \pm 0.01^{\mathrm{b}}$ & $0.27 \pm 0.00^{\mathrm{b}}$ & $0.22 \pm 0.00^{\mathrm{c}}$ \\
\hline (C10:0) Capric & $0.36 \pm 0.01^{\mathrm{b}}$ & $0.34 \pm 0.01^{\mathrm{c}}$ & $0.35 \pm 0.00^{\mathrm{b}}$ & $0.37 \pm 0.00^{\mathrm{a}}$ & $0.29 \pm 0.00^{\mathrm{d}}$ \\
\hline (C12:0) Lauric & $17.44 \pm 0.46^{\mathrm{a}}$ & $17.60 \pm 0.72^{\mathrm{a}}$ & $17.06 \pm 0.11^{\mathrm{a}}$ & $17.21 \pm 0.05^{\mathrm{a}}$ & $17.24 \pm 0.12^{\mathrm{a}}$ \\
\hline (C14:0) Myristic & $10.76 \pm 0.13^{\mathrm{a}}$ & $10.49 \pm 0.12^{\mathrm{b}}$ & $10.44 \pm 0.04^{\mathrm{b}}$ & $10.86 \pm 0.05^{\mathrm{a}}$ & $10.42 \pm 0.01^{\mathrm{b}}$ \\
\hline (C16:0) Palmitic & $10.81 \pm 0.04^{\mathrm{ab}}$ & $10.36 \pm 0.27^{\mathrm{c}}$ & $10.61 \pm 0.04^{\mathrm{b}}$ & $10.86 \pm 0.03^{\mathrm{a}}$ & $9.96 \pm 0.01^{\mathrm{d}}$ \\
\hline (C16:1) Palmitoleic & $0.06 \pm 0.00^{\mathrm{a}}$ & $0.05 \pm 0.01^{\mathrm{b}}$ & $0.06 \pm 0.00^{\mathrm{a}}$ & $0.06 \pm 0.00^{\mathrm{a}}$ & $0.04 \pm 0.01^{\mathrm{b}}$ \\
\hline (C17:0) Margaric & $0.05 \pm 0.00^{\mathrm{a}}$ & $0.05 \pm 0.01^{\mathrm{a}}$ & $0.05 \pm 0.00^{\mathrm{a}}$ & $0.05 \pm 0.00^{\mathrm{a}}$ & $0.00 \pm 0.00^{\mathrm{b}}$ \\
\hline (C18:0) Stearic & $4.83 \pm 0.06^{\mathrm{ab}}$ & $4.62 \pm 0.22^{\mathrm{c}}$ & $4.65 \pm 0.01^{\mathrm{bc}}$ & $4.88 \pm 0.01^{\mathrm{a}}$ & $4.20 \pm 0.04^{\mathrm{d}}$ \\
\hline (C18:1) Oleic & $45.43 \pm 0.49^{\mathrm{c}}$ & $46.98 \pm 0.29^{\mathrm{b}}$ & $46.69 \pm 0.06^{\mathrm{b}}$ & $45.63 \pm 0.04^{\mathrm{c}}$ & $49.58 \pm 0.18^{\mathrm{a}}$ \\
\hline (C18:2) Linoleic & $9.06 \pm 0.05^{\mathrm{a}}$ & $8.62 \pm 0.37^{b}$ & $9.04 \pm 0.01^{\mathrm{a}}$ & $9.06 \pm 0.06^{\mathrm{a}}$ & $7.60 \pm 0.03^{\mathrm{c}}$ \\
\hline (C20:1) Gondoic & $0.07 \pm 0.01^{\mathrm{a}}$ & $0.00 \pm 0.00^{\mathrm{b}}$ & $0.07 \pm 0.00^{\mathrm{a}}$ & $0.05 \pm 0.01^{\mathrm{b}}$ & $0.08 \pm 0.01^{\mathrm{a}}$ \\
\hline (C20:1) trans-gondoic & $0.23 \pm 0.01^{\mathrm{a}}$ & $0.16 \pm 0.01^{\mathrm{b}}$ & $0.21 \pm 0.01^{\mathrm{a}}$ & $0.19 \pm 0.01^{\mathrm{ab}}$ & $0.06 \pm 0.03^{c}$ \\
\hline (C20:0) Arachidic & $0.47 \pm 0.02^{\mathrm{a}}$ & $0.38 \pm 0.01^{\mathrm{c}}$ & $0.44 \pm 0.01^{\mathrm{b}}$ & $0.45 \pm 0.01^{\mathrm{ab}}$ & $0.24 \pm 0.01^{\mathrm{d}}$ \\
\hline$\Sigma \mathrm{SFA}$ & 45.14 & 44.16 & 43.90 & 44.98 & 42.60 \\
\hline$\Sigma$ MUFA & 45.80 & 47.21 & 47.05 & 45.96 & 49.79 \\
\hline$\Sigma$ PUFA & 9.06 & 8.63 & 9.05 & 9.07 & 7.61 \\
\hline TU & 54.86 & 55.84 & 56.01 & 55.03 & 57.40 \\
\hline TU/SFA index & 1.21 & 1.26 & 1.27 & 1.22 & 1.34 \\
\hline
\end{tabular}

¿SFA: saturated fatty acid; $\Sigma$ MUFA: monounsaturated fatty acid; $\Sigma$ PUFA: polyunsaturated fatty acid; TU: total unsaturated fatty acid; TU/SFA index: total unsaturated fatty acid/saturated fatty acid index. Determinations were made in triplicate and the data are reported as the mean. The collected data were submitted to analysis of variance (ANOVA), and were compared by a multiple comparison of means according to the least significant differences (LSD) test, at a significance level of 5\%. Means followed by same letter(s) in each row do not differ significantly.

treatment, myristic acid was found in a greater proportion $(10.42 \%)$ than palmitic acid $(9.96 \%)$. The composition of total SFA in the treatments averaged $44.54 \%$, and $42.60 \%$ in the control.

All the date seed oil treatments and the control exhibited higher amounts of TU than SFA. The date seed oil from the treatments contained total unsaturated fatty acids in the range of $54.86-56.01 \%$ for the Deglet Noor and Medjool treatments, and for the control it was higher at $57.40 \%$. The TU for the treatments were composed on average of $83.56 \%$ MUFA and 16.44\% PUFA, and 86.74 and $13.25 \%$ for the control.

The most prevalent MUFA among the oils from the treatments was oleic acid (C18:1), which ranged from $45.43-46.98 \%$, and control contained a higher amount at $49.58 \%$, although palmitoleic (C16:1), gondoic (C20:1) and trans-gondoic (C20:1) were found in trace amounts. All MUFA compounds were consistent in the treatments and control, except in the Khadrawy treatment, where gondoic (C20:1) was not found.

The date seed oil content is low in PUFA, and linoleic acid (C18:2) was the only one present in treatment and control. For the treatments it was detected at $8.63-9.07 \%$, but in the control it was lower than $7.61 \%$. In general, a lower degree in polyunsaturated fatty acids would reduce the susceptibility to oxidative deterioration, a characteristic which contributes to its stability during storage (Saafi et al., 2008).

\section{DISCUSSION}

The dimensions of the control seeds were lower than the treatment seeds, on average by 5.61 and $6.08 \%$ for length and diameter, respectively. The diameter of the treatment and seeds was lower than that reported by Bouhlali et al., (2017) by about $1.15 \mathrm{~cm}$, but in relation to the length of 2.75 $\mathrm{cm}$, the value was close for the Khadrawy treatment with $2.71 \mathrm{~cm}$, and for the other treatments this value moves away. For the control seeds, the result was even farther at $2.47 \mathrm{~cm}$.

The weight of the control seeds had lower mass compared to the mass of the treatment seeds, which was $8.33 \%$ below the lowest mass, which corresponded to Deglet Noor and $14.78 \%$ of the highest value, which corresponded to Medjool. The mass for the Medjool treatment reported in the present study was $1.42 \mathrm{~g}$, which was very close to the mass reported by Zaid and Wet (2002) of $1.5 \mathrm{~g}$. For the rest of the treatments, the weight was between $1.32-1.38 \mathrm{~g}$ and the control presented the lowest value of $1.21 \mathrm{~g}$. 
The oil content of treatment seeds, varied between 5.37 - $11.09 \% \mathrm{w} / \mathrm{w}$, for Medjool and Zahidi, respectively. For control seeds the oil content was the highest at $13.59 \% \mathrm{w} / \mathrm{w}$, on average 1.7 times greater than the treatments. The source of pollen from the Medjool cultivar on the female recipient palm of the same cultivar showed the lowest oil yield. This finding matched the results reported by Bouhlali et al., (2017) and Aljuhaimi et al., (2018), however, the source of pollen and pollination technique were not reported. Another challenge is the oil extraction process from date seeds since the seeds did not provide a high oil yield (GolshanTafti et al., 2017).

The Fatty acid profiles were consistent in the treatments with slight percentage variations. Margaric acid (C17:0), was found as trace (less than $0.058 \%$ ) in all treatments, but was not found in the control treatment.

The level of total unsaturated fatty acid content of date seed oil using the TU/SFA index showed that the control had a $34 \%$ higher content of unsaturation; while for the treatment the values were between 21 and $27 \%$. The high amount of oleic acid was very close $(44.92 \%)$ to that reported by Bouhlali et al., (2017) for the Medjool cultivar.

\section{CONCLUSIONS}

This study demonstrates that the mass, dimension, oil content and fatty acid profile of date seeds are influenced by pollen source. Here, the Deglet Noor, Khadrawy, Medjool and Zahidi cultivars were used to pollinate female palms of the Medjool cultivar, and the results were compared with control pollen, as used traditionally by Mexican farmers. The effect of the pollen source in the treatment was manifested by an increase in the size and weight of the seeds, but a reduction in the oil content compared to the control seeds was also observed.

The traditional method of pollination of the date palm of the Medjool cultivar, presented a greater yield of oil extraction from the date seed and a greater proportion of oleic acid compared to pollination with Medjool, Deglet Noor, Khadrawy or Zahidi cultivars. These results may contribute to the Mexican date industry in order to take advantage of the added value of date seeds as a source of good quality oil with high relative percentages of oleic acids and good shelf-life.

\section{ACKNOWLEDGMENTS}

The authors thank the National Council on Science and Technology (CONACYT), and the Corporative RUVA for the use of their facilities in the realization of this study. They are grateful to the
Engineering Institute of the Autonomous University of Baja California and the Department of Graduate Studies of Sonora State University, San Luis Rio Colorado, for their support in the development of this work.

\section{REFERENCES}

Abdelouauhhab Z, Arias-Jimenez EJ. 2002. Date palm cultivation, 1st edn. FAO, Rome.

Akbari M, Razavizadeh R, Mohebbi GH, Barmak A. 2012. Oil characteristics and fatty acid profile of seeds from three varieties of date palm (Phoenix dactylifera) cultivars in Bushehr-Iran. Afr. J. Biotechnol. 11, 12088-12093.

Aljuhaimi F, Ghafoor K, Özcan MM. 2012. Physical and chemical properties, antioxidant activity, total phenol and mineral profile of seeds of seven different date fruit (Phoenix dactylifera L.) varieties. Int. J. Food Sci. Nutr. 63, 84-89. https://doi.org/10.3109/09637486.2011.598851

Aljuhaimi F, Özcan MM, Adiamo OQ, Alsawmahi ON, Ghafoor K, Babiker EE. 2018. Effect of date varieties on physicochemical properties, fatty acid composition, tocopherol contents and phenolic compounds of some date seed and oils. J. Food Process Pres. 42, 13584-13590. https://doi. org/10.1111/jfpp.13584

AOAC 963.15. 2005. Official Methods of Analysis of Association of Official Agriculture Chemist. Association of Analytical Chemist, Washington, D.C. Fat in Cacao Products.

AOCS Ce 2-66. 1997. Official methods and recommended practices of the American oil chemists' society Method Ce 2-66. GLC ranges of Fatty acid composition. Champaign, IL: AOCS Press.

Barreveld WH. 1993. By-products of date packing and processing. [Online] FAO. Available at: http://www.fao.org/docrep/ t0681e/t0681e09.htm [Accessed 31 Mar. 2018]

Bouhlali ET, Alem C, Ennassir J, Benlyas M, Mbark AN, Zegzouti YF. 2017. Phytochemical compositions and antioxidant capacity of three date (Phoenix dactylifera L.) seeds varieties grown in the South East Morocco. J. Saudi Soc. Agric. Sci. 16, 350-357. https://doi.org/10.1016/j. jssas.2015.11.002

Cert A, Moreda W, Pérez-Camino MC. 2000. Methods of preparation of fatty acid methyl esters (FAME). Statistical assessment of the precision characteristics from a collaborative trial. Grasas Aceites 51, 447-456. https://doi. org/10.3989/gya.2000.v51.i6.464

Georgi L. 1982. Pollination Ecology of the Date Palm and Fig Tree: Herodotus. Classical Philol. 77, 224-228.

Golshan-Tafti A, Solaimani-Dahdivan N, Yasini-Ardakani SA. 2017. Physicochemical properties and applications of date seed and its oil. Int. Food Res. J. 24, 1399-1406.

Hussein F, Moustafa S, Mahmud L. 1979. The direct effect of pollen (metaxenia) on fruit characteristics of dates grown in Saudi Arabia. Proceedings of the 3rd Conference on the Biological Aspects of Saudi Arabia, 69-78.

Kabacoff RI. 2011. R in action. Data analysis and graphics with R. 2nd edition. Manning Publications, New York.

R Core Team. 2015. R: A language and environment for statistical computing. Vienna, Austria: R Foundation for Statistical Computing. Available from https://www.rproject.org/.

Rahnama AA, Rahkhodaei E. 2014. The effects of date pollinizer variety and pollination time on fruit set and yield of Medjhol date palm. J. Adv. Agric. 2, 67-71.

Saafi EB, Trigui M, Thabet R, Hammami M, Achour L. 2008. Common date palm in Tunisia: chemical composition of pulp and pits. Int. J. Food Sci. Technol. 43, 2033-2037.

Salomón-Torres R, Ortiz-Uribe N, Villa-Angulo R, VillaAngulo C, Norzagaray-Plasencia S, Garcia-Verdugo C. 2017. Effect of pollenizers on production and fruit characteristics of date palm (Phoenix dactylifera L.) cultivar 
Medjool in Mexico. Turk. J. Agric. For. 41, 338-347. https:// doi.org/10.3906/tar-1704-14

SIAP, 2017. Anuario estadístico de la producción agrícola. Available at: http://infosiap.siap.gob.mx/aagricola_siap_ gb/icultivo/index.jsp (accessed 9 February 2018).

Steel RGD, Torrie JH. 1980. Principles and procedures of statistics. 1st edition. McGraw Hill, New York.
Swingle WT. 1928. Metaxenia in the date palm possibly a hormone action by the embryo or endosperm. J. Hered. 19, 257-268. https://doi.org/10.1093/oxfordjournals.jhered.a102996

Zaid A, Wet PF. 2002. Chapter I: botanical and systematic description of the date palm. [Online] FAO Available at: http://www.fao.org/docrep/006/Y4360E/y4360e05.htm [Accessed 31 Mar. 2018]. 